https://doi.org/10.18778/7525-598-0.17

\title{
Mirella Korzeniewska-Wiszniewska
}

\section{Republika Serbska i Republika Serbii a Serbowie - sytuacja obecna i perspektywy}

Bośnia i Hercegowina (BiH), jako państwo w obecnym kształcie, powstała na mocy porozumienia z Dayton i w wyniku podpisania pokoju w Paryżu w grudniu 1995 r. Jako federacja składa się z dwóch członów: Republiki Serbskiej oraz Federacji Bośni i Hercegowiny (muzułmańsko-chorwackiej). Faktem jest, że to państwo sztuczne, a nawet sztucznie podtrzymywane. O przyczynach tego stanu pisali znawcy problemu, wskazując na różne przyczyny tego zjawiska, głównie związane $\mathrm{z}$ potrzeba przedstawienia międzynarodowego politycznego sukcesu Stanów Zjednoczonych, zaangażowanych w ten konflikt. Ponadto kontrowersje wzbudzała skomplikowana struktura administracyjna państwa, w której uczestniczyli zachodni przedstawiciele, oraz obecność międzynarodowych sił wojskowych, która trwa do dnia dzisiejszego ${ }^{1}$.

Faktem również jest, że poprzez utworzenie tego państwa zmuszono trzy zwaśnione ze sobą w mniejszym lub większym stopniu narody (Serbów, Chorwatów i Muzułmanów) do egzystencji w ramach wspólnych granic, nie zezwalając im na utworzenie odrębnych państw (co uniemożliwiały nie do końca rozwiązane wzajemne roszczenia terytorialne).

Sytuacja ta spowodowała, że praktycznie od razu zaczęto poszukiwać innych rozwiązań, które umożliwiłyby bardziej harmonijna współpracę i zacieśniły relacje pomiędzy terytoriami w kraju. Powstało kilka koncepcji odmiennych rozwiązań ustrojowo-administracyjnych, które zostaną opisane bardziej szczegółowo w dalszej części tekstu, jednak żadna z nich nie została zaaprobowana przez władze i obywateli BiH. Być może przyczyną tego było utrzymanie podziału narodowościowego w państwie przez następnych piętnaście lat, aż do dzisiaj.

Dodatkowo, od zakończenia wojen pojawiły się bodźce zewnętrzne, które nie sprzyjały budowaniu jednolitości państwowej. Na początku były to na pewno

${ }^{1}$ M. Waldenberg, Rozbicie Jugostawii. Od separacji Stowenii do wojny kosowskiej, Warszawa 2003, s. 229; Misje pokojowe ONZ, Ośrodek Informacji ONZ w Warszawie, http://www.unic.un.org.pl/misje_pokojowe/mzeu_unprofor.php; EUFOR ALTHEA (EU Military Operation in Bosnia and Herzegovina), http://www.msz.gov.pl/EUFOR,ALTHEA,\%28EU, Military,Operation,in,Bosnia, and,Herzegovina\%29,29544.html; SFOR. Stabilisation Force, http://www.nato.int/ SFOR/ (dostęp 13 I 2011). 
wzajemne, trudne do wybaczenia krzywdy. Jeśli chodzi o stronę serbską dochodził do tego fakt, że to właśnie jej przypisywano winę zarówno za rozpętanie wojny, jak i wszystkie tragedie z nią związane. Następnie pojawiła się sytuacja Kosowa południowej prowincji serbskiej - które zostało oderwane jednostronnym aktem niepodległości przez zamieszkującą tam większość albańską.

Przypadek kosowski wymaga uważniejszego przyjrzenia się ze względu na kontekst bośniacki. W 1999 r., w wyniku zbrojnego konfliktu serbsko-albańskiego, po stronie kosowskich Albańczyków stanął Sojusz Północnoatlantycki (a przede wszystkim Amerykanie). Kosowo, formalnie pozostajac w ramach Serbii, stało się protektoratem ONZ ze stacjonującymi tam wojskami NATO (od 2008 r. UE). Teoretycznie, zarówno zagraniczni dyplomaci, ale także liderzy kosowskich Albańczyków oraz Serbów przez osiem lat poszukiwali odpowiedniego rozwiązania dla statusu tej prowincji, prowadząc rozmowy i dyskusje w różnych częściach Europy oraz w Stanach Zjednoczonych. W praktyce obie strony wiedziały, że Albańczyków zadowoli jedynie pełna niepodległość, Serbów zaś podległość regionu Belgradowi. Serbowie byli świadomi, że międzynarodowa opinia publiczna państw, które miały wpływ na rozwiązanie tej patowej sytuacji, stała po stronie Albańczyków, co było jeszcze konsekwencją wojen lat 1991-1995. Uznanie niepodległości Kosowa stawało się bardzo prawdopodobne, gdy uwzględnimy w analizie problem działań Albańczyków i akceptowanej powszechnie w tym przypadku polityki faktów dokonanych. W tym kontekście pojawiły się równocześnie opinie, że uznanie tej niepodległości wywoła analogiczne do albańskich dążenia Serbów z Republiki Serbskiej BiH².

Istniało jednak kilka okoliczności, które rzeczywiście mogły doprowadzić do analogicznego rozwiązania sytuacji. Przede wszystkim faktem, który pozwolił Serbom przez osiem lat negocjacji traktować je poważnie i z zaangażowaniem (czego nie można było powiedzieć o Albańczykach ${ }^{3}$ ), był zapis rezolucji Rady Bezpieczeństwa ONZ nr 1244, który określał Kosowo jako prowincję serbska, i która taką miała pozostać po osiagnięciu kompromisu. Inne rozwiązanie byłoby złamaniem prawa międzynarodowego. Tak się też stało w lutym 2008 r., gdy rozpoczał się proces uznawania międzynarodowego niepodległości Kosowa. W tej sytuacji posunięcia te mogły dać bośniackim Serbom nadzieję, że złamanie jednej zasady prawnej spowoduje, że będzie można łamać kolejne, stojace również na drodze oczekiwań innego narodu. Niestety bardzo szybko przypadek kosowski określono jako pojedynczy precedens, bez możliwości powtórzenia, co nasuwa przykre pytania o wybiórcze stosowanie prawa przez światowe mocarstwa.

2 Rozmowy autorki z prof. Radmila Nakarada, Belgrad, luty 2004 r.; L. Valtner, Dodik: Hipotetički, sada $i$ RS može uradi što $i$ Albanci, „Danas. RS”, 23 VII 2010, http://www.danas.rs/danasrs/politika/dodik_hipoteticki_sada_i_rs_moze_da_uradi_sto_i_ albanci.56.html?news_id=195692 (dostęp 5 XII 2010).

3 Međunarodna zajednica ne zna šta će sa Kosovom, „Danas”, 8-9 XI 2003, http://www.danas.co.yu/20031108/vikend2.html (dostęp 12 II 2009). 
Analizując sytuację pomiędzy Republiką Serbską a Serbią oraz postawę Serbów z obu państw wobec wydarzeń przeszłych i bieżących, można wyodrębnić trzy zasadnicze płaszczyzny, które stanowią podstawę tej analizy: relacje oficjalne między Republiką Serbii a Republiką Serbską - jako członem BiH, oraz relacje nieoficjalne, które wprawdzie nie wpływają na oficjalną politykę państw, jednak oddziaływają na opinię publiczna i postawy społeczne w obu krajach. Ostatnią z nich są właśnie opinie dziennikarzy i obywateli, wyrażających swoje stanowisko na forach internetowych. Dodatkowo, aby scharakteryzować te relacje, należy przyjrzeć się sytuacji wewnętrznej w samej Republice Serbskiej, zwłaszcza w kontekście jej położenia w państwie i relacji Serbów z Chorwatami i Muzułmanami, co stanowi zasadniczy punkt wyjścia w analizie powyższych wątków.

\section{Sytuacja wewnętrzna w Republice Serbskiej BiH}

W 1995 r. - w momencie powstania państwa bośniackiego - strukturę federacji oraz przyjęte rozwiązania administracyjne uznano siłą rzeczy za najbardziej odpowiednie. Miały one na celu zarówno złagodzić zła atmosferę pomiędzy zwaśnionymi narodami, jak i zmusić je do rzeczywistej współpracy. Zgodnie z uchwaloną jeszcze 1 grudnia 1995 r. konstytucja, federacja składała się z dwóch członów, z których każdy zajmował około połowy powierzchni terytorialnej Bośni i Hercegowiny (Republika Serbska 49\%, Federacja BiH 51\%). Głową państwa było trzyosobowe kolegialne Prezydium, składające się $\mathrm{z}$ przedstawicieli: chorwackiego, muzułmańskiego i serbskiego, wybieranych w wyborach bezpośrednich, „na którego czele stoi przewodniczący - jest nim rotacyjnie przedstawiciel jednej z trzech narodowości"4.

$\mathrm{Na}$ takich samych zasadach rozwiązano kwestię władzy centralnej. Zgromadzenie Parlamentarne o kompetencjach ustawodawczych składa się z Izby Narodów i Izby Reprezentantów. W skład pierwszej z nich wchodzi piętnastu reprezentantów, z których 2/3 (dziesięć osób) pochodzi z federacji muzułmańsko-chorwackiej, 1/3 (pięć osób) z Republiki Serbskiej. Chorwaci i Muzułmanie wybierani sa przez delegatów (tej samej narodowości) do federacyjnej Izby Narodów. Serbskich delegatów wybiera Zgromadzenie Narodowe Republiki Serbskiej. Co więcej, quorum (dziewięcioosobowe) w trakcie posiedzeń uznawane jest wówczas, gdy stanowią je po trzy osoby z każdej z wymienionych narodowości ${ }^{5}$.

W skład Izby Reprezentantów wchodzi czterdziestu dwóch członków, a ich proporcje również wynoszą $2 / 3$ do 1/3. Wybierani są oni „w sposób bezpośredni na

\footnotetext{
${ }^{4}$ E. Bujwid-Kurek, Państwa pojugostowiańskie. Szkice politologiczne, Kraków 2008, s. 139.

${ }^{5}$ Tamże, s. 140.
} 
mocy ordynacji wyborczych przyjmowanych przez zgromadzenie parlamentarne poszczególnych podmiotów Federacji Bośni i Hercegowiny”6.

Tak więc twórcy konstytucji starali się zadbać o równy udział w rządzeniu na każdej płaszczyźnie politycznej i administracyjnej. Przykładem tego może być nawet mianowanie zagranicznych ambasadorów Bośni i Hercegowiny, gdzie z ogólnej ich liczby - 2/3 mogło pochodzić z Federacji BiH, 1/3 z Republiki Serbskiej. Wyjątek stanowi Trybunał Konstytucyjny. Składa się on z dziewięciu członków, z których czterech wyznaczanych jest przez Izbę Reprezentantów Federacji, dwóch przez Zgromadzenie Republiki Serbskiej. „Pozostałych trzech członków jest wyznaczanych przez Przewodniczącego Europejskiego Trybunału Praw Człowieka po konsultacji z Urzędem Prezydenckim”7. Ponadto każda z części federacji posiada własny rząd i parlament.

Mimo poszukiwania takich kompromisowych rozwiązań, które miały traktować główne narody państwotwórcze w jednakowy sposób, w zasadzie od razu pojawiły się waţpliwości, czy tego rodzaju rozwiązania ustrojowe mają rację bytu. Prawie natychmiast pojawiły się inne pomysły i propozycje, które miały zmienić system polityczny państwa i w sposób bardziej skuteczny doprowadzić do stabilizacji sytuacji w kraju i współpracy między obywatelami wszystkich nacji.

Jedną z nich była propozycja Dražena Budišy (z Chorwackiej Partii Socjalno-Liberalnej), która postulowała zniesienie federacji i utworzenie w to miejsce czternastu kantonów (po pięć dla Serbów i Muzułmanów, cztery dla Chorwatów). Inna propozycja wypłynęła z ugrupowania „Za Bośnię i Hercegowinę”. Zakładała ona również likwidację federacji i scentralizowanie państwa, opartego na samorządach lokalnych. Jeszcze inna koncepcja zakładała z kolei utworzenie jednolitego państwa, zdecentralizowanego, które funkcjonowałoby w oparciu o współpracę regionów wyposażonych w szerokie kompetencje. Była też taka, która optowała za pozostawieniem systemu federacyjnego, ale podstawowymi jednostkami byłyby regiony ${ }^{8}$. Wszystkie te pomysły zostały jednak odrzucone, pozostawiając państwo w niezmienionej strukturze, co miało swoje konsekwencje w szerszej perspektywie - odsuwały możliwość ubiegania się $\mathrm{BiH}$ o wstapienie do NATO, czy hamowały postępy na drodze integracji z Unią Europejska. Ponadto, mimo upływu lat, nie zostały podjęte żadne działania, aby wypełnić zadania wyznaczone przez UE, które miały podnieść standardy funkcjonowania państwa bośniackiego.

W nawiązaniu do pojawiajacych się koncepcji alternatywnych rozwiązań ustrojowych, warto zwrócić uwagę na te, które wprawdzie nie wzmocniłyby Bośni i Hercegowiny, ale jednak były brane pod uwagę przez polityków i niektórych przedstawicieli społeczności narodowych. I tak, niektórzy Serbowie uważali, że

\footnotetext{
${ }^{6}$ Tami̇e, s. 142.

${ }^{7}$ Tamże.

${ }^{8}$ Tamże, s. 137-138.
} 
Republika Serbska powinna się stać niezależnym bytem państwowym, który połączyłby się z Serbia, zaś niektórzy Chorwaci postulowali, aby Federacja Bośni i Hercegowiny uległa podziałowi, i że powinna powstać Chorwacka Republika Herceg-Bośni ${ }^{9}$

Mimo wszystko głównym założeniem politycznym, nad którym czuwała także zaangażowana w kwestię bośniacką wspólnota międzynarodowa, było dążenie do stabilizacji i demokratyzacji kraju. U progu XXI w. wydawało się, że zamierzenia te mogą się powieść - w 2001 r. powstał rząd, w którym nie znaleźli się po raz pierwszy od dziesięciu lat - przedstawiciele żadnej z partii o tendencjach nacjonalistycznych ${ }^{10}$.

Mimo to na płaszczyźnie społecznej obecne były nieco inne nastroje. W maju tego samego roku w Banja Luce - stolicy Republiki Serbskiej - doszło do zamieszek na tle etnicznym między Serbami a Muzułmanami. Przyczyną była uroczysta inauguracja budowy meczetu (zburzonego podczas wojny), której sprzeciwiali się wyznawcy prawosławia. W efekcie doszło do obrzucenia kamieniami przedstawicieli zagranicznych, m.in. szefa misji ONZ Jacquesa Kleina ${ }^{11}$.

Świadczyło to o wciąż żywych animozjach z okresu wojennego, zaś incydent ten nie był jedyny. W lipcu tego samego roku, podczas uroczystości związanych z 6. rocznicą wydarzeń w Srebrenicy, odsłonięto ufundowany przez Brytyjczyków obelisk, upamiętniajacy ofiary tego zdarzenia. Serbowie wystapili z inicjatywą wybudowania pomnika w hołdzie pamięci żołnierzy serbskich, którzy zginęli podczas wojen ${ }^{12}$.

Pomimo tych wydarzeń warto wspomnieć, że nieustannie trwały prace nad ekshumacjami osób poległych w wojnach w latach 1992-1995. Prowadziła je Komisja Współpracy, składająca się z przedstawicieli byłych republik jugosłowiańskich. Ponadto toczyły się procesy przeciwko zbrodniarzom wojennym wszystkich zwaśnionych stron ${ }^{13}$.

Wiosna 2002 r. parlament Republiki Serbskiej przyją poprawki do konstytucji, zwiększające prawa Chorwatów i Muzułmanów. Gwarantowały one dostęp do wysokich stanowisk $\mathrm{w}$ administracji państwowej i gospodarczej oraz 15\% udziału w rządzie. Poza tym szef rządu oraz dwaj jego następcy mieli być obsadzani według klucza etnicznego. Oprócz tego zrównane zostały alfabety i języki wszystkich trzech głównych narodowości. Na straży tych praw miała stać powołana Rada Ochrony Żywotnych Interesów Obywateli ${ }^{14}$.

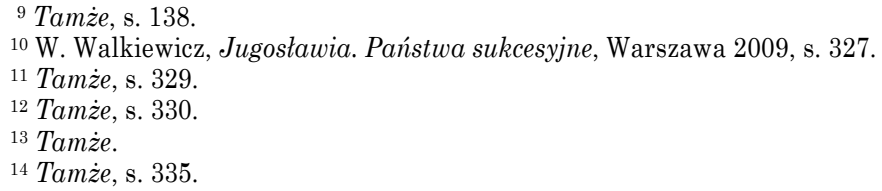


W momencie wybuchu wojny bośniackiej krajobraz etniczny w tej republice jugosłowiańskiej kształtował się w następujący sposób: Muzułmanie stanowili najliczniejsza grupe narodowa - 43,7\%, Serbowie - 31,3\%, Chorwaci - 17,3\%, Jugosłowianie $-5,5 \%$, Czarnogórcy - 0,3\% i inni - 1,9\% ${ }^{15}$. Wojna przyczyniła się do emigracji, wysiedleń i migracji w ramach byłej Jugosławii, zmieniając pejzaż etniczny republik. To jednak nie zmotywowało władz bośniackich do przeprowadzenia spisu powszechnego. Serbowie zarzucali, że był to efekt korzystnych szacunków z 1991 r., które wykazywały przewagę etniczną na korzyść Muzułmanów. Zarzuty wsparte były stwierdzeniami, że obawiali się oni, iż bieżacy spis wypadłby na korzyść Serbów. Według serbskich źródeł z 2005 r. w Bośni i Hercegowinie żyło 1698559 Muzułmanów, 1132014 Serbów i 510843 Chorwatów. W samej Republice Serbskiej Bośni i Hercegowiny żyło 916000 Serbów, 70000 Muzułmanów i 20000 Chorwatów $^{16}$.

Innym konfliktogennym tematem między narodami - a jednocześnie problemem hamujacym normalizację życia w $\mathrm{BiH}$ - była kwestia schwytania osób oskarżonych o zbrodnie wojenne i przekazanie ich Międzynarodowemu Trybunałowi Karnemu dla byłej Jugosławii w Hadze. Rodzinom ściganych oferowano wysokie miesięczne uposażenia, w zamian za oddanie poszukiwanych w ręce sprawiedliwości - na ogół bez skutku. Zaowocowało to frustracja administracji zachodniej i w efekcie Wysoki Przedstawiciel społeczności międzynarodowej Paddy Ashdown zdymisjonował władze policji w Pale oraz w serbskiej części Sarajewa. Gdy chodziło o poszukiwanie najbardziej znanych osób podejrzanych o zbrodnie, takich jak Radovan Karadžić czy Ratko Mladić, fundowano bardzo wysokie nagrody pieniężne. I tak za schwytanie R. Karadžicia Amerykanie wyznaczyli nagrodę w wysokości $5 \mathrm{mln}$ dolarów, i mimo że oficjalnie trwały intensywne poszukiwania byłego prezydenta Republiki Serbskiej, nie potrafiono go schwytać (analogicznie rzecz się miała, jeśli chodziło o gen. R. Mladicia) ${ }^{17}$.

Poza tymi jednoznacznymi problemami, które wymagały delikatnej polityki oraz skutecznego działania, do dysfunkcji państwa bośniackiego przyczyniały się dodatkowo inne czynniki. Jako przykład można podać jedna z największych bolączek tego kraju, jaką była korupcja, a jeszcze inna - brak dobrej organizacji państwowych instytucji18.

15 Leksykon państw świata '94/'95. Raport o stanie 192 państw świata, red. M.B. Michalik, K. Sobczak, Warszawa 1994, s. 79; P. Garde, Vie et mort de la Yougoslavie, Paris 1992, s. 116; M. Thompson, Paper House. The Ending of Yugoslavia, London 1992, s. 198.

${ }_{16} \mathrm{M}$. Labus, Bosna manja za milion duša, „Večernje novosti”, 5 IX 2005, http://www.novosti.rs/vesti/naslovna/aktuelno.69.html:173732-Bosna-manja-za-milion-dusa (dostęp 24 VIII 2010).

${ }_{17}$ W. Walkiewicz, $d z$. cyt., s. 417. Ostatecznie jednak obaj zostali zatrzymani w Serbii: R. Karadžić w lipcu 2008 r., natomiast gen. R. Mladić w maju 2011 r.

18 Tamże, s. 418 . 
Zaangażowani w pomoc dla $\mathrm{BiH}$ zagraniczni dyplomaci oraz zachodnie organizacje międzynarodowe metodą zachęt i ostrzeżeń usiłowały wywierać presję na bośniackie narody, w celu zacieśnienia współpracy i poprawy sytuacji w ogóle. Momentami polityka ta przynosiła poprawę, jak w 2005 r., gdy przedstawiciele władz Republiki Serbskiej wyrazili żal i przeprosili za wydarzenia, do których doszło w Srebrenicy w 1995 r., co miało być znakiem poprawy stosunków serbsko-muzułmańskich ${ }^{19}$.

Często jednak okazywało się, że poprawa relacji była incydentalna i w istocie powierzchowna. W tym samym roku podjęto kroki, które miały pomóc w integracji federacji, zmierzające do utworzenia wspólnych sił zbrojnych. Podczas zaprzysiężenia armii doszło do skandalu, gdy serbscy żołnierze odmówili złożenia przysięgi wobec państwa bośniackiego i złożyli ją wobec Republiki Serbskiej.

Istniał również problem we współpracy ze strukturami NATO. Powodem było zjawisko rozwijających się w Bośni nurtów radykalnego islamu, a nawet współdziałania z Al-Kaida, której członkowie walczyli w wojnie bośniackiej w pierwszej połowie lat 90 . XX w.

Mimo tych wszystkich trudności Bośnia i Hercegowina nie rezygnowała z dążeń do przystapienia do struktur Unii Europejskiej. W 2007 r. zostało parafowane Porozumienie o Stabilizacji i Integracji z UE ${ }^{20}$.

W lutym 2008 r. parlament Kosowa - w którym zasiadali w większości Albańczycy - ogłosił niepodległość. Fakt ten, mimo że nie stanowił dla Serbów zupełnej niespodzianki, wywołał jednak wstrzas wśród serbskiego społeczeństwa (zarówno z Republiki Serbskiej, jak i Republiki Serbii). Wpływ na tę reakcję miała w dużej mierze postawa Zachodu, który nie tylko przyzwolił na działania Albańczyków, ale i większość państw zachodnich uznała tę niepodległość. W Republice Serbskiej Bośni Serbowie manifestowali przeciwko temu i niemalże natychmiast pojawiła się kwestia, czy ta jednostronna decyzja, która miała moc państwotwórcza, uznaną dodatkowo na arenie międzynarodowej, nie będzie miała wpływu na spójność państwa bośniackiego. Pojawiły się obawy, że kosowski precedens mógłby wywołać podobne ruchy $w$ regionie i na świecie. Część serbskich polityków i serbskiej opinii publicznej podchwyciła myśl, że skoro dopuszczono do oderwania części terytorium suwerennego państwa, do czego przyczyniła się wola większości mieszkańców tego terytorium, analogicznie Republika Serbska mogłaby ogłosić niepodległość i odłączyć się od Bośni i Hercegowiny. Szybko pojawiły się jednak opinie polityków amerykańskich, że kwestia kosowska była wyjatkiem, nie zaś precedensem, co miało uspokoić obawy międzynarodowej opinii publicznej. Zabieg ten nie do końca się jednak udał.

19 Tamże, s. 419

${ }^{20}$ D. Stojaković, Paraf u Bosni, „Večernje novosti”, 4 XII 2007, http://www.novosti.rs/ vesti/naslovna/aktuelno.69.html:206518-Paraf-u-Bosni (dostęp 24 VIII 2010). 
Część krajów Unii Europejskiej - np. Hiszpania, Słowacja czy Cypr - nie uznały tej niepodległości.

Nie wywierano również presji na władze $\mathrm{BiH}$, aby poparły utworzenie nowego państwa, zaś zagraniczni dyplomaci zapewnili, że nikt tego nie będzie wymagał od państwa bośniackiego. Co więcej, ze zrozumieniem potraktowano postawę Serbów. Niewykluczone, że to pełne zrozumienia stanowisko Zachodu wobec bośniackich Serbów wynikało z przekonania, że wydarzenia kosowskie pozostaną bez wpływu na sytuację w $\mathrm{BiH}$.

Nie można również wykluczyć, że taka opinia Zachodu była celowym zabiegiem politycznym, majacym uświadomić bośniackim Serbom, że ich dążenia separatystyczne nie zostaną poparte przez międzynarodową opinię publiczną. Mimo to, wydarzenia z lutego 2008 r. nie pozostały bez wpływu na serbskie społeczeństwo. Już $\mathrm{w}$ następnym roku do opinii publicznej zaczęły trafiać medialne komentarze, że Republika Serbska zmierzała do coraz większej autonomii, zamiast współpracować z Chorwatami, Muzułmanami i Sarajewem. Z kolei osiagnięta autonomia miała być wstępem do uzyskania niepodległości, a następnie - co było prawdopodobne - do przyłączenia się do Republiki Serbii. Określanie kosowskiego przypadku mianem bezprecedensowego wyjątku nie było dla Serbów argumentem. Co więcej, zarzucali oni administracji międzynarodowej, urzędującej w Sarajewie, że jej polityka przyczyniała się do łamania postanowień z Dayton, poprzez dążenie do centralizacji państwa bośniackiego ${ }^{21}$.

Warto również wspomnieć o tym, że bośniaccy Serbowie nie byli jedynymi, którzy podgrzewali w kraju atmosferę napięcia, serwując opinii publicznej informacje o podziale Bośni. Również wśród Chorwatów z Federacji Bośni i Hercegowiny pojawiły się nurty, postulujące przyłączenie części terytorium do macierzy. W roku 2009 pojawiły się konkretne inicjatywy pokojowego odłączenia się od BiH. Przyczyną tego miało być fiasko porozumień daytońskich, których postanowienia nie zostały $\mathrm{w}$ pełni wprowadzone $\mathrm{w}$ życie w ciagu ostatnich piętnastu lat, a współżycie głównych trzech narodów nie układało się w takim stopniu, w jakim zakładano to w 1995 r. Stanowisko takie prezentowała chorwacka organizacja pozarządowa o nazwie „Kroacija libertas”, której przewodniczył Leo Pločkinić. Główny problem - według niej - stanowiła dominacja Muzułmanów, islamizacja kraju i marginalizowanie Chorwatów oraz Serbów. Ponadto należy zauważyć, że Chorwaci z Bośni i Hercegowiny posiadali jednocześnie obywatelstwo Republiki Chorwacji, przyznane jeszcze przez

21 Ž. Pantelić, Mirna je Bosna, ,Večernje novosti”, 29 II 2008, http://www.novosti.rs/ vesti/naslovna/aktuelno.69.html:211343-Mirna-je-Bosna (dostęp 22 VIII 2010); Nema priznavanija Kosova, „Večernje novosti”, 12 V 2009, http://www.novosti.rs/vesti/planeta. 70.html:239757-Nema-priznavanja-Kosova (dostęp 22 VIII 2010); Independent: BiH se raspada, Srbima autonomia, „Večernje novosti”, 13 VIII 2009, http://www.novosti.rs/vesti/ naslovna/aktuelno.69.html:248047-Indipendent-BiH-se-raspada-Srbima-autonomija (dostęp 24 VIII 2010). 
prezydenta Franjo Tuđmana (zapewnił sobie swojego czasu tym gestem poparcie dla własnej osoby) $)^{22}$.

Oprócz Serbów i Chorwatów, również Muzułmanie nie byli do końca zadowoleni z charakteru i kształtu państwa; niewykluczone, że i wśród nich pojawiły się idee utworzenia homogenicznego państwa, promowane przecież od lat 70 . XX w. przez muzułmańskiego „ojca narodu” Aliję Izetbegovicia. Fakt ten wzmacniał rozwój radykalnego islamu w Bośni i Hercegowinie, który następował od czasu wojny w latach 1992-1995, a do którego przyczynili się przybysze z muzułmańskich krajów Bliskiego Wschodu, walczący niejednokrotnie jako mudżahedini przeciwko Serbom i Chorwatom. Jednym z najbardziej kontrowersyjnych zjawisk, poruszanych również ostatnio w literaturze naukowej, był rozwój wahhabizmu w $\mathrm{BiH}$. Co więcej, wśród samych bośniackich Muzułmanów zaczęto odnotowywać wzrost aktywności ruchów nacjonalistycznych, które miały zagrażać swoim działaniem „Serbom, Żydom, Romom i chorwackim separatystom”23.

Tak więc, obserwując postawy państwowotwórcze bośniackich narodów, można było odnieść wrażenie, że BiH - kraj o kruchych podwalinach i jeszcze delikatniejszych strukturach - ma wszelkie podstawy, aby nie przetrwać. Kwestia dalszego bytu powróciła w 2008 r., po ogłoszeniu niepodległości przez parlament kosowski. Według badań opinii publicznej, przeprowadzonych przez Instytut Gallupa, na pytanie: „Czy ogłoszenie przez Kosowo niepodległości będzie miało wpływ na przyszłość Bośni i Hercegowiny?" - 60\% mieszkańców Federacji Bośni i Hercegowiny odpowiedziało negatywnie, natomiast przeciwnego zdania byli mieszkańcy Republiki Serbskiej, gdzie 60\% dało pozytywną odpowiedź. W tych samym badaniach za niepodległa Republiką Serbską opowiedziało się 88\% mieszkańców tej części federacji ${ }^{24}$. Można więc stwierdzić, że oficjalna postawa obywateli nieserbskiej części, mimo wyżej opisanych zjawisk oraz postawy Serbów, cechowała się umiarkowanym optymizmem co do przyszłości państwa. W sumie jednak, według badań, większość mieszkańców nie wierzyła w przetrwanie własnego kraju.

22 Hrvati traže razdvajanje od Bošnjaka, „Večernje novosti”, 18 III 2009, http://www.novosti.rs/vesti/planeta.70.html:234736-Hrvati-traze-razdvajanje-od-Bosnjaka (dostep 16 VIII 2010); N. Kopač, Mesić zaustavljen iz Herceg-Bosne, „Večernje novosti”, 3 I 2005, http://www.novosti.rs/vesti/planeta.70.html:165327-Mesi263-zaustavljen-iz-Herceg-Bosne (dostęp 18 VIII 2010).

${ }^{23}$ M.J. Zacharias, Komunizm - federacja - nacjonalizmy. System władzy w Jugosławii 1943-1991. Powstanie, przekształcenie, rozkład, Warszawa 2004, s. 409; S. Mišljenović, Nova Handžar divizija, „Večernje novosti”, 12 II 2010, http://www.novosti.rs/vesti/ planeta.70.html:265075-Nova-Handzar-divizija (dostep 24 VIII 2010); E. Vljaki, Tko su prave Vehabije, „Nezavisne novine”, 4 II 2010, http://www.nezavisne.com/kolumne/vijesti/52730/ Tko-su-prave-Vehabije.html (dostęp 3 IX 2010).

${ }^{24}$ Za nezavisnu RS 88 odsto građana, „Danas. RS”, 5 XII 2010, http://www.danas.rs/ danasrs/svet/region/za_nezavisnu_rs_88_odsto_gradjana.9.html?news_id=204069 (dostęp 5 XII 2010). 


\section{Relacje oficjalne między Republiką Serbską a Republiką Serbii}

Mimo tak pesymistycznych nastrojów, bośniaccy obywatele przystosowywali się do istniejących struktur, realizując jednocześnie partykularne dążenia narodowe, które były zbliżone do tych z lat 90. XX w., o które faktycznie walczono. Głównie ta kwestia dotyczyła Serbów i Chorwatów, którzy sprawiali wrażenie, że więcej zaangażowania wkładaja w utrzymywanie kontaktów z krajami macierzystymi aniżeli w rozwój Bośni i Hercegowiny. Była to kolejna przyczyna, dla której nie ufali sobie nawzajem.

Gdy w marcu 2001 r., w Banja Luce - stolicy Republiki Serbskiej - podpisano porozumienia, regulujące stosunki tej części kraju z Federacyjną Republiką Jugosławii (FRJ), wywołało to protesty ze strony Chorwatów, mimo że w zamiarze polityków BiH i FRJ było również uregulowanie tej kwestii między obydwoma państwami. Nastapiło to w połowie tego samego roku, poprzez podpisanie umowy „O powołaniu wspólnej rady na rzecz poprawy wzajemnych stosunków”25.

Jak pokazały następne lata, relacje między obydwoma państwami przebiegały dwupłaszczyznowo. Na płaszczyźnie oficjalnej były one dobre, lecz do tego dochodziły kontakty, które nie były zaliczane do serbskiej i bośniackiej polityki zagranicznej. Wpływały one jednak znacząco na opinię publiczną, różniąc się równocześnie od linii oficjalnej - o nich w dalszej części rozważań. Ta rozbieżność wynikała, przynajmniej w przypadku Republiki Serbii, z konkretnych powodów: łagodna i pokojowa postawa, budująca dobre kontakty z sasiadami, była niezbędnym kierunkiem politycznym w dążeniu do Unii Europejskiej.

Nie uniknięto jednak incydentów między obydwoma krajami. W 2009 r. doszło do jednego na płaszczyźnie dyplomatycznej, kiedy to Belgrad wyraził sprzeciw wobec przyjęcia bośniackiego ambasadora, Seada Avdicia. Człowiek ten miał za sobą wojenną przeszłość i ciążyły na nim zarzuty m.in. udziału w masakrze na żołnierzach Jugosłowiańskiej Armii Ludowej w Tuzli, gdzie sprawował wysoki urząd w tamtejszych władzach ${ }^{26}$.

Nie wpłynęło to jednak na politykę zagraniczną Serbii wobec Bośni i Hercegowiny - nadal deklarowała ona chęć współpracy w rozwiązywaniu problemów. Jesienia tego samego roku doszło w Belgradzie do spotkania ministra spraw zagranicznych Republiki Serbii Vuka Jeremicia z Wysokim Przedstawicielem w BiH Miroslavem Lajčákiem. Obaj politycy zgadzali się co do działań tzw. wspólnoty międzynarodowej, w które powinna być w pełni zaangażowana na rzecz pomocy Republice Bośni i Hercegowiny, aby ta mogła osiąnaçc stabilizację.

25 W. Walkiewicz, dz. cyt., s. 313, 316 .

${ }^{26}$ Analogiczny incydent miał miejsce w Chorwacji w 2005 r. - D. Stojaković, Zapelo oko agermana, „Večernje novosti”, 16 VIII 2009, http://www.novosti.rs/vesti/naslovna/ aktuelno.69.html:248564-Zapelo-oko-agermana (dostęp 24 VIII 2010). 
Argumentem było to, że rzeczywiście kraj ten był właśnie tworem tzw. wspólnoty międzynarodowej ${ }^{27}$.

Oficjalnie Zachód postrzegał i postrzega do dnia dzisiejszego relacje między Serbią a Bośnią i Hercegowiną jako dobre ${ }^{28}$. W ostatnich dwóch latach doszło do spotkań na wysokim szczeblu pomiędzy głównymi politykami obu państw, co jest $\mathrm{w}$ pewnej mierze zabiegiem powiązanym $\mathrm{z}$ procesem integracji. Niewykluczone jest również to, że Serbia chce w końcu wykorzystać fakt, że po ogłoszeniu niepodległości przez Kosowo, państwa zachodnie przyspieszą proces integracyjny, co miało być nieformalną i nieoficjalną rekompensatą za utraconą prowincję. Naturalnie, ta swoista rekompensata nigdy nie będzie oficjalnie potwierdzonym gestem.

W dniu 6 grudnia 2010 r. prezydent Serbii Boris Tadić przebywał z wizyta w Banja Luce. Spotkał się tam z Bakirem Izetbegoviciem (jednym z członków Prezydium $\mathrm{BiH}$ ) oraz prezydentem Chorwacji Ivo Josipoviciem. Stwierdził wówczas, że dla dobra i stabilizacji regionu trzeba rozwiąać wewnętrzne problemy, a przede wszystkim te dotyczące wysiedleń, własności i granic. Zaznaczył też, że dotyczy to całego regionu, ponieważ Muzułmanie, Serbowie i Chorwaci żyją nie tylko w BiH, ale i w Chorwacji, i w Serbii. Ogłoszony został nowy etap stosunków między Belgradem a Sarajewem. Tym gestom wtóruja opinie serbskich naukowców z uniwersytetu w Banja Luce, którzy zauważają potrzebę rozwinięcia dialogu w państwie bośniackim ${ }^{29}$.

\section{Kontakty nieoficjalne a ich wpływ na sytuację między krajami}

Oprócz relacji oficjalnych duży wpływ na serbską opinię publiczną miały te nieformalne. Można do nich zaliczyć kontakty znanych osób z życia publicznego, mających wpływy opiniotwórcze, które swoim - również publicznym - działaniem

${ }^{27}$ Lajčak i Jeremić za zajedničko rešavanje problema u BiH, „Večernje novosti”, 2 X 2009, http://www.novosti.rs/vesti/naslovna/aktuelno.69.html:252781-Lajcak-i-Jeremicza-zajednicko-resavanje-problema-u-BiH (dostęp 25 VIII 2010).

${ }^{28}$ N. Vrzić, Evropska Komisija: Srbija na evropskom prutu, „Pečat”, 11 XI 2010, http://www.pecat.co.rs/2010/11/evropska-komisija-srbija-na-evropskom-prutu/ (dostęp 7 XII 2010).

${ }^{29}$ Tadić: Budućnost regiona u EU, Radio-Televizija Vojvodine, 6 XII 2010, http://www.rtv. rs/sr_lat/politika/tadic:-buducnost-regiona-u-eu_226918.html; Tadić: Nova etapa odnosa Sarajeva i Beograda, „Kurir”, 6 XII 2010, http://www.kurir-info.rs/vesti/politika/tadicnova-etapa-odnosa-sarajeva-i-beograda-63370.php; M. Filipović, Dogovor za bolji region, „Večernje novosti”, 6 XII 2010, http://www.novosti.rs/vesti/planeta.70.html:310459-Dogovorza-bolji-region. Zob. też: B. Marić, Kulturu strahopoštovanja zameniti kulturom razgovora, „Politika online”, 7 XII 2010, http://www.politika.rs/rubrike/region/Kulturu-strahopostovanjazameniti-kulturom-razgovora.lt.html (dostęp 8 XII 2010). 
lub słowami kształtowały postawę grup społecznych. Przykładem takim mógł być zwycięzca jugosłowiańskich wyborów prezydenckich z 2000 r. Vojislav Koštunica, postrzegany przez Zachód na początku pierwszej dekady XXI w. jako demokrata o centroprawicowych poglądach. Jesienią 2002 r., w czasie wiecu w Zvorniku (w Republice Serbskiej), powiedział on, że „Republika w Bośni jest tylko chwilowo odłączona od macierzy”, co oburzyło władze z Sarajewa i dobitnie świadczyło o tym, że V. Koštunica nie podzielał drogi rozwoju dobrych stosunków z bośniackim sasiadem. W rzeczywistości słowa byłego prezydenta FRJ nie mogły być zaskoczeniem dla Serbów, znających jego poglądy jeszcze z lat 90. XX w.; jednak międzynarodowa opinia publiczna nieświadoma była faktu, że podczas wojny w BiH popierał on politykę R. Karadžicia i bośniackich Serbów. Niewykluczone, że jego głos inspirował część serbskiej opinii publicznej w Bośni i Hercegowinie, wpisując się w aktualizację nacjonalistycznych nastrojów wśród narodów. Już wcześniej wśród ludności serbskiej panowały opinie, że na pewno zostanie przeprowadzone referendum w sprawie politycznego samookreślenia Republiki Serbskiej. Takie słowa, jak te V. Koštunicy, tylko umacniały to przekonanie. W każdym razie w wyborach lokalnych, parlamentarnych i prezydenckich, które miały miejsce $\mathrm{w}$ tym czasie, prym wiodły ugrupowania nacjonalistyczne, promując partykularne interesy narodowe, które okazały się być ważniejsze od stabilizacji w państwie ${ }^{30}$.

Prezydent Republiki Serbskiej Milorad Dodik (były premier i przewodniczący Związku Niezależnych Socjaldemokratów - SNSD), mimo iż zbliżony poglądami do V. Koštunicy, był bardziej ostrożny w słowach, jak przystało na aktualnego prezydenta. Stwierdził on bowiem, że „dla bośniackich Serbów nie byłaby problemem Bośnia, w której ludność serbska dobrze by się czuła, ale musiałaby to być inna Bośnia, nie ta, w której żyli, i w której islam - religia większości narodu $\mathrm{BiH}$ - zmierzał ku radykalizacji” 31 .

Między początkiem a końcem pierwszej dekady XXI w. nie można zauważyć szczególnej ewolucji w kwestii zmiany spojrzenia na kluczowe problemy, określajace charakter zarówno stosunków serbsko-bośniackich, jak i serbsko-serbskich. W marcu 2010 r. parlament Republiki Serbii, po trzynastogodzinnej debacie, uchwalił deklarację, oceniajaca wydarzenia w Srebrenicy w 1995 r., w której potepiono zbrodnie, wyrażono współczucie i przeproszono ofiary również za to, że nie dołożono starań, aby powstrzymać tę tragedię. Wyrażono również chęć kontynuowania pełnej współpracy z Międzynarodowym Trybunałem Karnym dla byłej Jugosławii, zwłaszcza w celu ujęcia R. Mladicia (byłego generała wojsk Republiki Serbskiej). Parlament wezwał również wszystkie skonfliktowane ze

30 W. Walkiewicz, dz. cyt., s. 336 .

${ }_{31}$ Dodik: Referendum je neizbežan, „Večernje novosti”, 3 IX 2006, http://www.novosti. rs/vesti/naslovna/aktuelno.69.html:187744-Dodik-Referendum- je-neizbezan (dostęp 24 IV 2010). 
sobą w przeszłości narody Bośni i Hercegowiny do współpracy, poszanowania równości i zapobiegania w przyszłości zbrodniom ${ }^{32}$.

W kwietniu 2010 r., gdy doszło do spotkania V. Koštunicy z liderem Serbskiej Partii Demokratycznej (SDS) Republiki Serbskiej Bośni - Mladenem Bosiciem, obaj politycy doszli do wniosku, że mimo deklaracji, współpraca między obydwoma republikami nie jest zadowalająca. Poruszona została również kwestia przyjęcia przez parlament Republiki Serbii Deklaracji Parlamentu Republiki Serbii, potepiajacej zbrodnie w Srebrenicy, co - zdaniem M. Bosicia - mogło w przyszłości być szkodliwe dla Republiki Serbskiej Bośni, m.in. dlatego, że przyjęto w niej oficjalnie odpowiedzialność za te wydarzenia ${ }^{33}$.

Mimo że stanowisko to podzielała prawdopodobnie większa część serbskiej opinii publicznej, istniały opinie, takie jak ta Čedomira Jovanovicia, lidera Partii Liberalno-Demokratycznej, że deklaracja jest zbyt słaba w wydźwięku w stosunku do samego wydarzenia. Powodem miało być choćby uniknięcie umieszczenia w deklaracji słowa „ludobójstwo" 34 .

Warto również zwrócić uwagę na czwarty - ostatni punkt deklaracji w której parlament serbski „wyraził nadzieję, że najwyższe autorytety innych państw z obszaru byłej Jugosławii również potępią zbrodnie popełnione na przedstawicielach narodu serbskiego, złożą wyrazy współczucia i przeproszą rodziny serbskich ofiar" 35 . Tak więc w punkcie tym Serbowie, po przyjęciu wcześniej odpowiedzialności za wydarzenia w Srebrenicy - co uczynili w zasadzie w imieniu wszystkich Serbów zamieszkujących terytoria byłej Jugosławii podkreślili jednak, że również i oni byli ofiarami w tym konflikcie w stopniu, który zasługuje na takie same przeprosiny. Nie jest to stanowisko bezpodstawne.

\section{Opinie prasowe i internetowe}

Deklaracja Parlamentu Republiki Serbii wywołała duże poruszenie w społeczeństwie serbskim i sprowokowała komentarze na ten temat na forach internetowych. Na łamach portalu internetowego „Pečat”, określanego „portalem wolnej Serbii”, autorka tekstu pt. Zapomniane serbskie ofiary - Anja Vujević - podkre-

32 Declaration of the National Assembly of the Republic of Serbia Condemning the Crime in Srebrenica, http://www.parlament.gov.rs/files/eng/pdf/2010/ deklaracija\%20ENG1.pdf (dostęp 30 I 2011)

33 S. Čngradin, Po uzoru na peticiju Dveri, „Danas. RS”, 21 II 2010, http://www.danas.rs/ danasrs/politika/po_uzoru_na_peticiju_dveri_.56.html?news_id=184183 (dostęp 5 XII 2010).

34 Serbia: Parlament potepit masakre $w$ Srebrenicy, http://fakty.interia.pl/ swiat/news/serbia-parlament-potepil-masakre-w-srebrenicy,1458936; D. Mikucka-Wójtowicz, Polityczne przepychanki $z$ Srebrenica $w$ tle, http://www.polis.edu.pl/index.php?option= com_content\&task=view\&id=150\&Itemid=66 (dostęp 30 I 2011).

35 Declaration of the National Assembly of the Republic... 
ślała, że uchwalenie przez parlament tego dokumentu pozostanie bez wpływu na relacje serbsko-bośniackie, ze względu na fakt, że - według niej - czegokolwiek Belgrad nie zrobiłby i tak nie zadowoli Sarajewa. Przyjęcie tej deklaracji miało spowodować możliwości wywierania nacisku politycznego na Republikę Serbii i Republikę Serbską w przyszłości. Było to również nic innego, jak przerzucanie kolektywnej odpowiedzialności na wszystkich Serbów za wydarzenia, które miały miejsce w Srebrenicy w 1995 r. Autorka podkreśliła, że o Srebrenicy mówiło się wybiórczo, bez uwzględnienia przyczyny wydarzeń, która leżała z kolei w wydarzeniach z 1942 i 1992 r., a także w 1993 r., gdy w wiosce Skelani wymordowano serbskich cywilów ${ }^{36}$.

Inny problem dotyczył sytuacji wewnętrznej w Bośni i Hercegowinie. Strona serbska zarzucała bośniackim sąom, że nie były niezawisłe i dbały przede wszystkim o ochronę Muzułmanów, którzy byli podejrzani o popełnienie zbrodni w czasie wojen lat 1992-1995. Według A. Vujević, Serbowie prowadzili politykę zbyt kompromisową wobec Zachodu w imię osiagnnięcia celów politycznych również dotyczy to M. Dodika. Jako przykład podała stanowisko prezydenta Republiki Serbskiej wobec kwestii niepodległości Kosowa. Zapewnił on wprawdzie, że Republika Serbii oraz Bośnia i Hercegowina nie uznają tej niepodległości, to jednak widział rozwiązanie problemu w podziale spornego obszaru między Serbów i Albańczyków (warto wspomnieć, że był to jeden z projektów rozwiązania problemu kosowskiego, wysuwany przez Belgrad w 2007 r. ) $^{37}$.

Wśród innych komentarzy internetowych można było znaleźć opinie Serbów na temat uchwalenia tej deklaracji parlamentarnej - zdecydowana większość występowała przeciwko jej przyjęciu. Charakterystyczna była wypowiedź internauty, podpisującego się jako Mladen Mladenović, który argumentował swoje stanowisko twierdząc, że dokument ten sporządzony został przez Stany Zjednoczone oraz UE i przypisywał zbrodnie wszystkim Serbom z byłej Jugosławii. Inny forumowicz, ukrywajacy się pod nickiem Slavwe, podobnie jak M. Mladenović zaznaczył, że pewne fakty znane były powszechnie, nie tylko serbskiej opinii publicznej, i w znaczacy sposób wpływały na postrzeganie wydarzeń w Srebrenicy. Mimo to utrzymywana była propagandowa wersja na temat tych zdarzeń. Wśród faktów wymieniano i ten, że w strefie chronionej przez Holendrów ukrywał się batalion wojsk muzułmańskich pod przywództwem słynnego gen. Nasera Oricia. Ponadto ekshumacje z rejonu Srebrenicy, przeprowadzane przez międzynarodowe grupy, zidentyfikowały w ciagu piętnastu lat 3,8 tys. ciał - Muzułmanów, Chorwatów i Serbów - a mimo to wciąż podawana jest w różnych źródłach liczba ofiar tzw. masakry srebrenickiej od 4 do 12 tys. Muzułmanów ${ }^{38}$.

36 A. Vujević, Republika Srpska. Zaboravljene srpske žrtve, „Pečat”, 1 IV 2010, http://www.pecat.co.rs/2010/04/2420/ (dostęp 8 XII 2010).

${ }^{37}$ Tamże,

38 Zob. więcej: S. Čongradin, Po uzoru na peticiju Dveri, „Danas. RS”, 21 II 2010, http://www.danas.rs/danasrs/politika/po_uzoru_na_peticiju_dveri_.56.html?news_id=184183; 
Niepochlebne stanowisko wobec aktualnych władz belgradzkich przedstawił były minister spraw zagranicznych FRJ Živadin Jovanović, który skrytykował Zachód za bezprawne uznanie niepodległości Kosowa. Co więcej, krytykował serbskie władze, że zamiast budować dobre relacje z przyjaznymi Serbii państwami (Rosja, Chinami, Indiami, Brazylia), obrały pozbawioną alternatywy drogę, na siłę forsując współpracę z politykami stojącymi za „agresją NATO z 1999 r., odłączeniem Czarnogóry i jednostronnym ogłoszeniem niepodległości Kosowa"39.

Komentarze internautów były również praktycznie jednomyślne, gdy chodziło o stanowisko wobec potencjalnej separacji Republiki Serbskiej od Bośni i Hercegowiny. Prawo do ewentualnej niepodległości, o której mieliby zadecydować obywatele Republiki Serbskiej, oparto nie na analogii z wydarzeniami kosowskimi, gdzie wola większości doprowadziła do niepodległości. Nie przyjmowano argumentów o wyjątkowej sytuacji Kosowa. Co więcej, w wypowiedziach internautów można było znaleźć uzasadnienia twierdzące, że likwidacja bośniackiego organizmu państwowego przyniosłaby wreszcie stabilizację w regionie, której nie można było osiagnać w ciagu ostatnich piętnastu lat ${ }^{40}$.

Warto jednak wspomnieć o stanowisku publicystów z czasopisma „Republika" (sekcji z Republiki Serbskiej). Periodyk ten zawsze publikował opinie niezależnych opozycjonistów z lat 90. XX w., jednak głównie tych, którzy nie sympatyzowali ani z władzą Slobodana Miloševicia, ani z nacjonalizująca opozycją spod znaku Vuka Draškovicia czy V. Koštunicy. W roku 2010 ostro oceniali politykę prezydenta Serbii B. Tadicia, krytykując go za zbyt bliskie stosunki z M. Dodikiem, zaniedbywanie relacji z centralnymi władzami BiH. Co więcej, przez taka politykę zaangażowania po stronie ziomków z Bośni i Hercegowiny, ani Chorwacja, ani Serbia nie były gwarantem stabilności państwa bośniackiego. Wręcz przeciwnie, B. Tadić miał traktować serbską część kraju podobnie jak S. Milošević kiedyś traktował Kosowo, a powinien - ich zdaniem - pozwolić bośniackim Serbom iść własną drogą polityczną w ramach $\mathrm{BiH}^{41}$.

Periodyki z Republiki Serbskiej regularnie donosiły o sytuacji w Republice Serbii. Dużo też było doniesień na temat Kosowa. Co ciekawe, nie było w zasadzie

por. C. Savich, Srebrenica and Naser Oric. An Analysis of General Philippe Morillon's Testimony at the ICTY, http://www.srebrenica-project.com/index.php?option=com_content\& view=article\&id=1:2009-01-07-18-16-23\&catid=3:2009-01-06-17-56-50\&Itemid=4 (dostęp 5 XII 2010).

${ }^{39}$ U. Mrdić, Beograd Vido politiku samoponižavanja, „Pečat”, 23 VII 2010, http://www.pecat.co.rs/2010/07/zivadin-jovanovic-beograd-vodi-politiku-samoponi-zavanja/ (dostep 8 XII 2010).

${ }^{40}$ Zob. więcej: http://www.danas.rs/danasrs/svet/region/za_nezavisnu_rs_88_odsto_ gradjana.9.html?news_id=204069 (dostęp 5 XII 2010).

${ }^{41}$ L. Manojlović, Pogled iz Bosne i Hercegovine. Tadić, Dodik i Harčenko, „Republika”, 1.10.-30.11.2020, br. 486-489, http://www.republika.co.rs/486-489/10.html (dostęp 8 XII 2010). 
informacji na temat położenia Serbów w Republice Chorwacji. Niewykluczone, że było to spowodowane przeświadczeniem, że „kwestia chorwacka” była przesądzona i ewentualne zmiany terytorialne $\mathrm{w}$ tamtym rejonie nie były dla Serbów sprawą otwarta. Twierdzenie to jednak należy potraktować jako czystą spekulację $e^{42}$.

\section{Zakończenie}

Według Wiesława Walkiewicza, w połowie pierwszej dekady XXI w. pojawiły się opinie, że podpisanie porozumień z Dayton nie zakończyło wojny w Bośni i Hercegowinie, a jedynie „przesunęło ją do innej kategorii konfliktu” ${ }^{3}$.

Porozumienie z Dayton zakładało, że Serbowie z Republiki Serbskiej nie będą mieli prawa do secesji i dlatego, w związku z takim zapisem, przedstawiciele tego narodu czuli i czują się nadal pokrzywdzeni. Pamiętano bowiem, ze Konstytucja Socjalistycznej Federacyjnej Republiki Jugosławii z 1974 r. dawała formalne prawo każdej narodowości państwowotwórczej do separacji i możliwość utworzenia niezależnego organizmu państwowego. Faktyczne oddzielenie republiki od Jugosławii nastapiło dopiero na początku lat 90. XX w., ale przecież nie poprzez wykorzystanie konstytucyjnej drogi prawnej, ale w sprzyjajacych warunkach międzynarodowych, po upadku systemów komunistycznych w bloku wschodnim. Niemniej, fakt istnienia takiego zapisu konstytucyjnego pozostał w świadomości wielu, a brak takich zapisów w porozumieniach z Dayton, a raczej podkreślanie zupełnej ich odwrotności, miały sprzyjać spójności Bośni i Hercegowiny jako państwa i wyeliminować potencjalne dylematy narodów co do życia we wspólnocie politycznej. Okazało się jednak, że zakaz separacji nie tylko nie miał żadnego wpływu na proces jednoczenia (a raczej jego brak), ale zadziałał wręcz odwrotnie - nawet prowokująco. Serbowie wciąż czuja więź z Serbami z Republiki Serbii, nie zaś z Muzułmanami i Chorwatami. Analogicznie, Chorwaci czują więź z Republiką Chorwacką i są skłonni do współpracy z nią właśnie niż z Serbami.

W polityce serbskiej mamy do czynienia $\mathrm{z}$ dwoistością stanowisk. Z jednej strony konstruowane są relacje między Serbią a Bośnią i Hercegowina, z drugiej zaś pojawiają się opinie polityków, że secesja Republiki Serbskiej Bośni z federacji jest tylko kwestia czasu. Nie chodzi tylko o jednoznaczna w swych przekonaniach postawę V. Koštunicy, ale również można wymienić tutaj działania prezydenta Serbii B. Tadicia, czy ministra spraw zagranicznych V. Jeremicia. Z jednej strony, w oficjalnych stosunkach, zapewniali oni o po-

${ }^{42}$ Zob. Granata na srpsku kuću, „Glas Srpske”, 15 XI 2010, http://www.glassrpske.com/ vijest/8/srbija/48775/lat/Granata-na-srpsku-kucu.html (dostęp 7 XII 2010).

${ }^{43}$ W. Walkiewicz, $d z$. cyt., s. 436. 
szanowaniu integralności terytorialnej BiH, z drugiej zaś - wspierali premiera, a następnie prezydenta Republiki Serbii M. Dodika, który nie wyklucza separacji Republiki Serbskiej. Ten dwugłos pokazuje, że politycy serbscy przekazuja sprzeczne ze sobą komunikaty: inne dla dyplomacji zachodniej, inne zaś dla pobratymców. Jednak w samej Republice Serbii opinia publiczna jest podzielona, zaś wśród niej mniejszość stanowią ludzie, którzy z powodu własnych przekonań wspierają stanowisko prezentowane przez Serbię w oficjalnej polityce międzynarodowej. Chodzi tu nie tylko o akceptację obecnego porządku na terytorium byłej Jugosławii, ale o przyjęcie odpowiedzialności za czyny i wydarzenia z ostatnich dwudziestu lat w sposób, który jest dla wielu Serbów całkowicie nie do zaakceptowania. Takie stanowisko reprezentował choćby lider Partii Liberalno-Demokratycznej Č. Jovanović oraz jego zwolennicy.

Najjaskrawiej widać było to w przypadku kosowskim. Gdy nastapiło odłaczenie Kosowa od Serbii, wydawało się, że jest to wydarzenie dla Serbów nie do przyjęcia. Szybko jednak pojawiły się opinie, powtarzane zresztą przez opisywaną część społeczeństwa i właśnie Partię Liberalno-Demokratyczna, że zdominowane przez Albańczyków Kosowo i tak było stracone od kilku lat. Jovanović podkreślał również, że Serbii faktycznie nie było stać na utrzymywanie tej problematycznej prowincji. Co więcej, kraj nie miał pomysłu na ułożenie harmonijnej koegzystencji z Albańczykami ${ }^{44}$.

Obecnie pojawia się coraz więcej opinii, że B. Tadić, polityk proeuropejski, dopuszcza możliwość nieformalnego uznania suwerenności tej byłej serbskiej prowincji. Warto przypomnieć, że w 2008 r. optował on za zerwaniem stosunków dyplomatycznych z każdym państwem, które uznałoby niepodległość Kosowa ${ }^{45}$. Bezsprzecznie jest to dowód, że Serbia jest w stanie pójść na daleko posunięte kompromisy dla spełnienia standardów demokratycznego państwa w oczach Zachodu. Celem jest oczywiście przystapienie do Unii Europejskiej, która zgodnie ze swą polityką powinna w przyszłości „znieść” granice na Bałkanach.

W listopadzie 2010 r. były ambasador Stanów Zjednoczonych w Belgradzie i Zagrzebiu William Montgomery wywołał poruszenie, zarówno wśród polityków bałkańskich, jak i na Zachodzie, swoim stwierdzeniem, że Bośnia i Hercegowina

44 D. Bujošević, Kosovo je već nezavisno, „NIN”, 9 VI 2005, http://www.nin. co.yu/pages/article.php?id=20857 (dostęp 14 II 2009).

${ }_{45}$ N. Tomić, Stuaranje budućnosti za Srbiju i Kosovo, „Danas. RS”, 5 XII 2010, http://www.danas.rs/dodaci/vikend/stvaranje_buducnosti_za_srbiju_i_kosovo.

26.html?news id=205022 (dostep 5 XII 2010); Sve loše je već učinjeno, „Danas. RS”, 29 X 2010, http://www.danas.rs/dodaci/vikend/sve_lose_je_vec_ucinjeno.26.html?news_id=202545 (dostęp 5 XII 2010); S. Basara, Moć dezorientacije, „Danas. RS”, 5 X 2010, http://www.danas.rs/ danasrs/kolumnisti/moc_dezorijentacije. 881.html?news_id=200794 (dostęp 5 XII 2010); Nastaviti uspešnu saradnju, „Danas. RS”, 5 IX 2010, http://www.danas.rs/danasrs/ politika/nastaviti_uspesnu_saradnju.56.html?news_id=198609 (dostęp 5 XII 2010). 
to państwo, „które przepadło i w którym nic nie funkcjonuje” 46 . Nazwał je też „upadłym projektem i szkolnym przykładem podzielonego państwa” ${ }^{47}$. Taka opinia wywołała szok wśród bośniackich polityków, zaś przedstawiciele Partii Akcji Demokratycznej stwierdzili, że jest to wyłącznie prywatna opinia W. Montgomery'ego. Jednakże opinii tej wtóruje stanowisko byłego amerykańskiego sekretarza stanu Henry'ego Kissingera, który w równie bezpośrednich słowach stwierdził: „głupotą było uznanie Bośni i Hercegowiny jako niezależnego państwa” ${ }^{48}$. Następnie dodał, że „należy utworzyć niezależne państwo muzułmańskie, a pozostałym pozwolić, aby utworzyli swoje niezależne kraje lub przyłączyli się odpowiednio do Serbii lub Chorwacji”"

${ }^{46}$ A. Vujević, Cepanje Bosne $i$ Hercegovine, „Pečat”, 4 XI 2010, http://www.pecat. co.rs/2010/11/cepanje-bosne-i-hercegovine/ (dostęp 7 XII 2010).

${ }^{47}$ Tamże.
${ }^{48}$ Tamże. 